\title{
Surgical treatment of bilateral femoral stress fractures related with long-term alendronate therapy
}

\author{
Uzun süreli alendronat tedavisi ile ilişkili iki taraflı femur stres kırığının cerrahi tedavisi
}

\author{
Ulunay Kanatı, MD., M. Baybars Ataoğlu, MD., Mustafa Özer, MD., \\ H. Nevzat Topçu, MD., Mehmet Çetinkaya, MD. \\ Department of Orthopedics and Traumatology, Medical Faculty of Gazi University, Ankara, Turkey
}

\begin{abstract}
A 67-year-old female patient admitted to our outpatient clinic suffering from pain in both thighs for one year without any history of trauma. Patient was receiving alendronate therapy for five years. Physical examination revealed pain increasing with weight-bearing in both thighs with full range of hip and knee movements. Radiographs showed an area of thickened cortex of middle femoral diaphysis in both femurs, but no fracture. Bone scan showed a single area of increased uptake of radioisotope. These images were compatible with stress fractures of both femurs. Dual-energy X-ray absorptiometry revealed a T-score of -3.2 for the lumbar spine and -3.5 for the hip. Alendronate treatment was ceased. Calcium and vitamin D treatment were started. Patient was performed prophylactic surgical stabilization by titanium elastic nails in May 2009. On first day after the surgery, unsupported mobilization and weight-bearing activities were started. Upon persistence of pain on left thigh, plate fixation was performed for the nonunion in June 2012. Patient is now pain-free and able to walk with full weight-bearing without any complications.
\end{abstract}

Keywords: Alendronate, femoral fracture, fracture fixation, stress fracture.

Osteoporosis is a major health problem characterized by compromised bone strength ${ }^{[1]}$ The number of people with osteoporosis increases as the population ages. Increasing number of osteoporotic fractures may have a negative impact on economics and quality of life of patients. ${ }^{[2]}$ Bisphosphonates are synthetic analogues of pyrophosphate and have been used effectively in the treatment of osteoporosis with considerable clinical benefit in reduction of bone fragility for many years. They impair bone resorption by inhibition of osteoclast
$\ddot{O} Z$

Travma öyküsü olmadan her iki uyluğunda bir yıldır devam eden ağrısı olan 67 yaşında bir kadın hasta polikliniğimize başvurdu. Hasta beş yıldır alendronat tedavisi görmekteydi. Fizik muayenede her iki uylukta ağırlık verilen aktivitelerle artan ağrı, kalça ve dizlerde tam hareket açıklığı saptandı. Röntgen filmleri her iki femur orta diyafizde kalınlaşmış korteks alanı görüldü fakat kırık yoktu. Kemik taramasında tek bir alanda artmış radyoizotop tutulumu görüldü. $\mathrm{Bu}$ görüntüler her iki femur stres kırığı ile uyumluydu. Çift-enerji X-1şın absorpsiyometride T-skoru bel omuru için -3.2 , kalça için -3.5 bulundu. Alendronat tedavisi durduruldu. Kalsiyum ve D vitamini tedavisi başlandı. Hastaya Mayıs 2009'da titanyum elastik çivi ile profilaktik cerrahi tespit uygulandı. Cerrahi sonrası birinci günde desteksiz mobilizasyon ve tam ağırlık verilen aktivitelere başlandı. Sol uylukta ağrının devam etmesi üzerine Haziran 2012'de kaynamama için plak ile fiksasyon uygulandı. Hasta şu anda ağrısızdır ve tam ağırlık ile komplikasyonsuz yürüyebilmektedir.

Anahtar sözcükler: Alendronat, femur kırığı, kırık tespiti, stres kırığı.

function and reducing osteoclast number. This gives rise to bone turnover diminution and bone mineral density (BMD) improvement resulting in fracture risk reduction. ${ }^{[3]}$ Bisphosphonates are known to be safe and effective agents in short-term usage. Osteoblast function decreases due to inhibition of osteoclast function and impair bone turnover for prolonged periods. Over-suppression of bone turnover results with impairment of remodelization ability of bone with long-term exposure to bisphosphonates. This

- Received: May 17, 2015 Accepted: October 28, 2015

- Correspondence: Mustafa Özer, MD. Gazi Üniversitesi Tıp Fakültesi Ortopedi ve Travmatoloji Anabilim Dalı, 06500 Beşevler, Ankara, Turkey Tel: +90 555 - 5180042 Fax: +90 312 - 2129008 e-mail: mozer208@yahoo.com 
causes accumulation of low energy micro damage, resulting in bone fragility, which could normally be repaired in healthy bone tissue. ${ }^{[4,5]}$ A number of case studies have shown increased bone fragility with prolonged bisphosphonate therapy. ${ }^{[6-9]}$ In this article, we report a patient who received longterm bisphosphonate therapy and presented with bilateral femur diaphysis stress fractures. Our article emphasizes the importance of taking possible stress fractures into consideration in patients with long-term bisphosphonate therapy, who present with vague thigh pain.

\section{CASE REPORT}

A 67-year-old female patient presented to the department of orthopaedics suffering from pain in both thighs for one year without any history of trauma. Her medical history included diabetes mellitus, diaphragmatic hernia, gastroesophageal reflux, hypothyroidism, menopause at the age of 49 , and osteoporosis. Five years ago, the reason of the pain was initially thought to be osteoporosis. She was administered oral alendronate treatment ever since. A written informed consent was obtained from the patient. Physical examination revealed pain in both thighs increasing with weight-bearing activity. Body mass index was $28 \mathrm{~kg} / \mathrm{m}^{2}$. Thyroid function tests were normal. Biochemical markers of bone turnover were normal. The patient's diabetes mellitus was controlled with oral antidiabetic drugs. Radiographic examination showed an area of thickened cortices of middle femoral diaphysis on both extremities but no evidence of fracture (Figure 1). Bone scanning with technetium$99 \mathrm{~m}$ showed a single area of increased uptake of
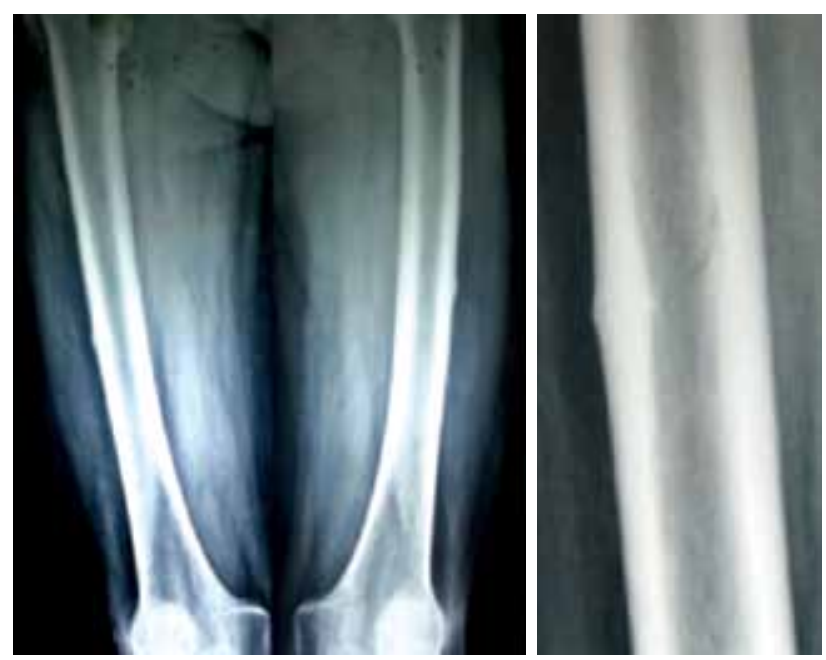

Figure 1. Area of thickened cortices of middle femoral diaphysis on both extremities. radioisotope in the middle third of the diaphysis of both femurs corresponding to the site of cortical thickening (Figure 2). These images were compatible with microfractures (stress fracture) of both femurs. Dual-energy $\mathrm{X}$-ray absorptiometry revealed $\mathrm{T}$ score of -3.2 for lumbar spine and -3.5 for hip. Despite the bisphosphonate treatment, no improvement in BMD was seen compared to previous evaluations. We thought that stress fractures may be associated with long-term usage of bisphosphonates and we discontinued alendronate treatment. Femoral stress fractures were treated by titanium elastic nails in May 2009 (Figure 3). However, upon persistence of pain on left thigh, plate fixation was performed for nonunion in June 2012 (Figure 4). Both femoral stress

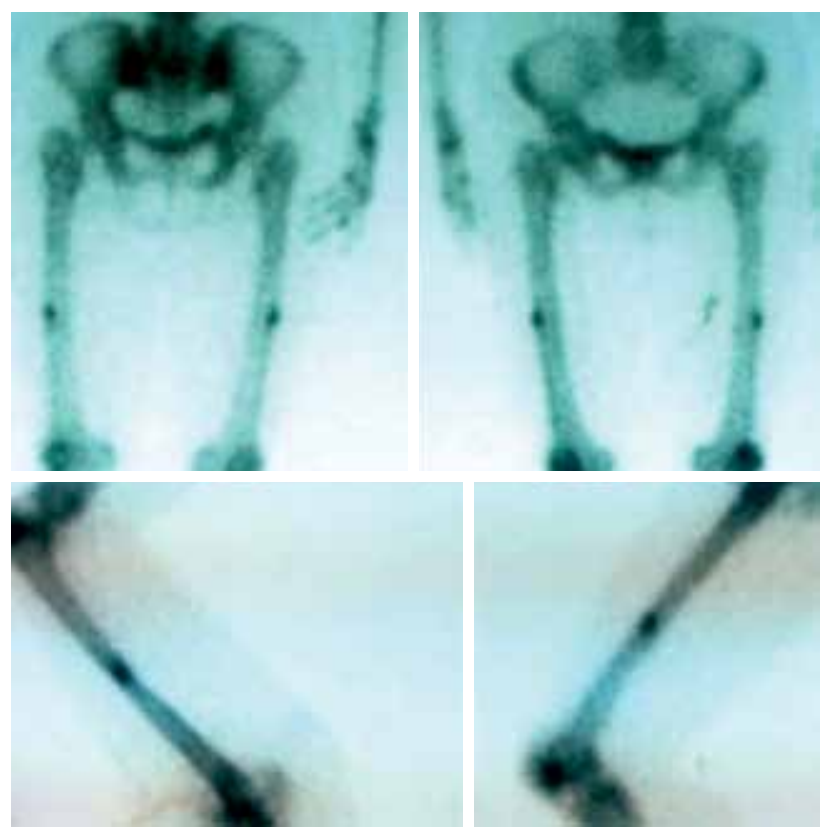

Figure 2. Area of increased uptake of radioisotope in middle diaphyseal region of both femurs at site of cortical thickening.
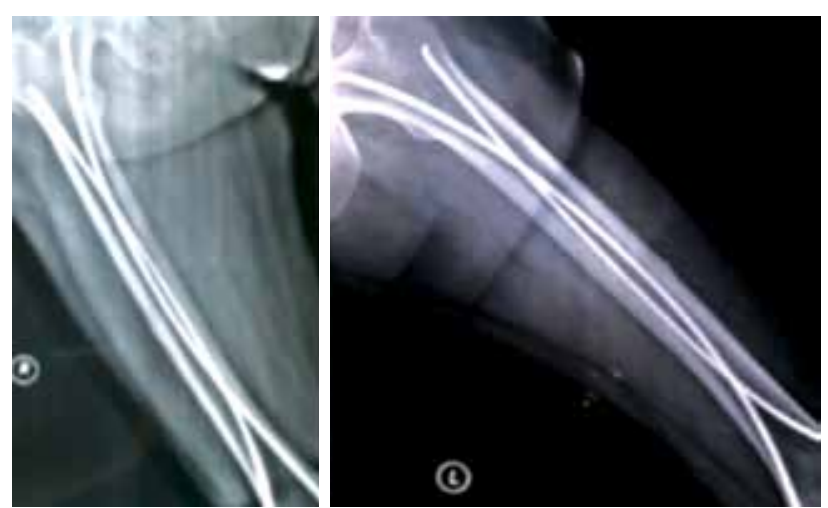

Figure 3. Femoral stress fractures were treated with titanium elastic nails. 


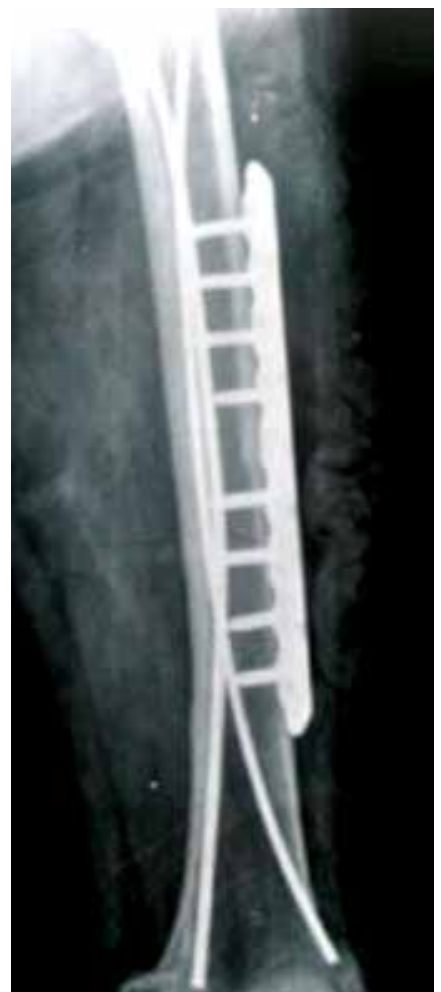

Figure 4. Plate fixation was performed for nonunion to left femur.

fractures healed uneventfully. The patient is painfree and has no problem with full weight-bearing activity.

\section{DISCUSSION}

Bisphosphonates have been used as a first line treatment modality for osteoporosis and reduction of related fracture risks. With prolonged bisphosphonates usage, impairment of bone remodeling increases. This causes accumulation of micro damage and susceptibility to fractures which are usually short oblique or transverse. ${ }^{[8-10]}$ These fractures radiologically demonstrate thickening of the lateral cortical margin of bone which is described as "beaking" as in our patient. ${ }^{[9]}$ The effects of alendronate take effect for at least five years after discontinuation of the drug.[11] Some authors recommend stopping alendronate intake after five years in most patients. ${ }^{[5]}$ Additional studies are needed to determine how long bisphosphonates can be used safely. Cortical thickening has a higher risk of progressing to complete stress fractures. ${ }^{[10]}$ Insufficiency fracture is a type of stress fracture and has three characteristic fracture patterns consisting of cortical thickening, transverse fracture, and medial cortical spike in subtrochanteric and femoral shaft regions ${ }^{[9]}$ The fracture lines of our patient were short oblique with lateral cortical thickening. Although the bulky muscles of the thigh prevented the proper palpation of the femur, it could be detected in early stage. However, the sensitivity of plain radiographs in the early stages may be as low as $10 \%$, rising to between $30 \%$ and $70 \%$ at follow- up. ${ }^{[12-15]}$

The majority of patients often describe a prodromal pain in thigh for several weeks or even months before the occurrence of the fracture. Importantly, at the investigation process, if stress fractures are detected prior to displacement, prophylactic fixation should be considered. It is unclear whether bisphosphonate therapy should be stopped or not. The preferred implant reported in the literature for the fixation of these fractures is rigid intramedullary nails with locking screws. Long cephalomedullary nails are now being considered for fixation, particularly to treat the subtrochanteric fractures. For our patient, we stopped bisphosphonate therapy and performed elastic nails to stimulate healing by micro-movement at the fracture line while not triggering stress rising point at the end of the nail.

Close monitoring of patients on long-term bisphosphonates is necessary. ${ }^{[16,17]}$ Recently, Odvina et al. ${ }^{[10]}$ reported nine patients who sustained atypical spontaneous fractures while on alendronate therapy for three to eight years. Six of the nine patients had delayed or absent fracture healing for four months to two years during alendronate therapy, and four showed delayed fracture healing for eight to 12 months even after discontinuation of alendronate. The nonunion of the left femoral shaft fracture of our patient might be due to the lasting effects of the longterm bisphosphonate therapy after cessation while the right femoral shaft fracture healed at third month. Visekruna et al..$^{[18]}$ reported on three patients with atypical subtrochanteric stress fractures who were on long-term alendronate, and one of them had no radiographic proof of union at 22 months. Many other reports described patients who experienced femoral stress fractures while on bisphosphonate therapy and delayed union or nonunion of the femoral shaft fracture despite discontinuation of bisphosphonates. It is thought that suppression of bone turnover caused by long-term usage of bisphosphonates is related to bone healing problems. Of atypical femoral fractures, $26 \%$ were reported to be delayed union. ${ }^{[19]}$ Our patient's symptoms for right thigh ended at the third month after the surgery. However, the patient was still suffering from the pain of her left thigh. The persisting left thigh pain was not affecting her daily life. Thus, we decided to follow-up the 
patient until the union. Unfortunately, at the end of the third year, the pain was still persisting, and there was no evident union. Then, patient underwent osteosynthesis surgery and was free of pain of her left and right thighs after five months.

In conclusion, although previous studies have shown the efficacy of bisphosphonates in the first five years of therapy, additional studies are needed to determine how long bisphosphonates can be given safely. We recommend discontinuing alendronate after five years. Patients who have been on long-term bisphosphonates should be evaluated in terms of fracture. When stress fracture is detected, prophylactic fixation should be considered to prevent progression to complete fracture and the fracture should be monitored closely for healing.

\section{Declaration of conflicting interests}

The authors declared no conflicts of interest with respect to the authorship and/or publication of this article.

\section{Funding}

The authors received no financial support for the research and/or authorship of this article.

\section{REFERENCES}

1. Juhász K, Boncz I, Patczai B, Mintál T, Sebestyén A. Risk factors for contralateral hip fractures following femoral neck fractures in elderly: analysis of the Hungarian nationwide health insurance database. Eklem Hastalik Cerrahisi 2016;27:146-52.

2. Atik OS, Gunal I, Korkusuz F. Burden of osteoporosis. Clin Orthop Relat Res 2006;443:19-24.

3. Drake MT, Clarke BL, Khosla S. Bisphosphonates: mechanism of action and role in clinical practice. Mayo Clin Proc 2008;83:1032-45.

4. Isaacs JD, Shidiak L, Harris IA, Szomor ZL. Femoral insufficiency fractures associated with prolonged bisphosphonate therapy. Clin Orthop Relat Res 2010;468:3384-92.

5. Ayanaoğlu T, Atik OŞ, Tokgöz N, Uçar M. Sacral and pubic insufficiency fractures due to bisphosphonate treatment. Eklem Hastalik Cerrahisi. 2015;26:120-4.
6. Atik OS, Oztürk AM, Kunat C, Cetinkaya M, Kaptan Y. Do atypical femoral fractures in patients with prolonged alendronate treatment heal? Eklem Hastalik Cerrahisi 2014;25:52-5.

7. Capeci CM, Tejwani NC. Bilateral low-energy simultaneous or sequential femoral fractures in patients on long-term alendronate therapy. J Bone Joint Surg Am 2009;91:2556-61.

8. Stepan JJ, Burr DB, Pavo I, Sipos A, Michalska D, Li J, et al. Low bone mineral density is associated with bone microdamage accumulation in postmenopausal women with osteoporosis. Bone 2007;41:378-85.

9. Kwek EB, Goh SK, Koh JS, Png MA, Howe TS. An emerging pattern of subtrochanteric stress fractures: a long-term complication of alendronate therapy? Injury 2008;39:224-31.

10. Odvina CV, Zerwekh JE, Rao DS, Maalouf N, Gottschalk FA, Pak CY. Severely suppressed bone turnover: a potential complication of alendronate therapy. J Clin Endocrinol Metab 2005;90:1294-301.

11. Black DM, Schwartz AV, Ensrud KE, Cauley JA, Levis S, Quandt SA, et al. Effects of continuing or stopping alendronate after 5 years of treatment: the Fracture Intervention Trial Long-term Extension (FLEX): a randomized trial. JAMA 2006;296:2927-38.

12. Schilcher J, Aspenberg P. Incidence of stress fractures of the femoral shaft in women treated with bisphosphonate. Acta Orthop 2009;80:413-5.

13. Lenart BA, Neviaser AS, Lyman S, Chang CC, EdoborOsula F, Steele B, et al. Association of low-energy femoral fractures with prolonged bisphosphonate use: a case control study. Osteoporos Int 2009;20:1353-62.

14. Niva MH, Kiuru MJ, Haataja R, Pihlajamäki HK. Fatigue injuries of the femur. J Bone Joint Surg Br 2005;87:1385-90.

15. Kiuru MJ, Pihlajamäki HK, Ahovuo JA. Bone stress injuries. Acta Radiol 2004;45:317-26.

16. Abrahamsen B, Eiken P, Eastell R. Subtrochanteric and diaphyseal femur fractures in patients treated with alendronate: a register-based national cohort study. J Bone Miner Res 2009;24:1095-102.

17. Lee $P$, Seibel MJ. More on atypical fractures of the femoral diaphysis. N Engl J Med 2008;359:317.

18. Visekruna M, Wilson D, McKiernan FE. Severely suppressed bone turnover and atypical skeletal fragility. J Clin Endocrinol Metab 2008;93:2948-52.

19. Koh JS, Goh SK, Png MA, Kwek EB, Howe TS. Femoral cortical stress lesions in long-term bisphosphonate therapy: a herald of impending fracture? J Orthop Trauma 2010;24:75-81. 